7 (2016)

DOI: $10.18276 /$ rk.2016.7-14

Agnieszka Borysowska

Książnica Pomorska w Szczecinie

\title{
Szczecin i ryby. Wokół przekładu opisu miasta Paula Friedeborna (1572-1637)
}

Podczas konferencji poświęconej dawnemu piśmiennictwu pomorskiemu, którą zorganizowało w 2014 roku Archiwum Państwowe w Szczecinie i Uniwersytet Szczeciński, jeden z uczestników apelował o podjęcie wysiłku publikowania źródeł historycznych dotyczących przeszłości regionu, zwłaszcza zaś o przygotowanie ich tłumaczeń (Migdalski: 12, 29-30). Ogłoszona właśnie edycja oraz przekład dzieła zatytułowanego Descriptio urbis Stetinensis [Opis miasta Szczecina], wydają się odpowiadać na tę potrzebę. Książka ukazała się w jednej z literaturoznawczych serii ostatnich lat, z którą specjaliści edytorstwa tekstów dawnych od początku wiązali duże nadzieje (Gruchała: 16) - „Bibliotece Dawnej Literatury Popularnej i Okolicznościowej” pod redakcją Romana Krzywego, jako jej 28. tom (Friedeborn, 2016). Seria ta, o czym zaświadcza także tekst Opisu miasta, wpisuje się w postulowaną przez fachowców potrzebę ogłaszania nowych edycji dzieł epok dawnych, szczególnie utworów prozatorskich, których współcześnie wydaje się znacznie mniej niż poetyckich (Gruchała: 17-18).

Pierwodruk Opisu miasta ukazał się w 1624 roku w Szczecinie w oficynie Nicolausa Bartholdiego. Autorem był szczecinianin, Paul Friedeborn ${ }^{1}$ (1572-1637), przedstawiciel zasłużonej dla miasta, bogatej rodziny kupieckiej. Był on od 1597 roku sekretarzem miejskim, a w czasie pracy nad swoim dziełem od kilku lat także rajcą (od 1616). Natomiast zwieńczeniem jego kariery w służbie publicznej stała się godność burmistrza, którą uzyskał w roku 1630 i sprawował do śmierci.

Niektóre zagadnienia poruszone przez Friedeborna w Opisie miasta pojawiały się wcześniej w utworach innych autorów (Borysowska, 2016: 6-10), ale także i on

1 Na temat biografii P. Friedeborna zob. Borysowska, 2016: 5-31 (tu dalsza bibliografia). 
sam nie podejmował tematyki zupełnie dla siebie nowej. W roku 1613 opublikował w Szczecinie obszerną, napisaną po niemiecku, historię miasta zatytułowaną $\mathrm{Hi}$ storische Beschreibung der Stadt Alten Stettin in Pommern. W książce tej przedstawił dzieje miasta od czasów najdawniejszych po sobie współczesne. Przy jej pisaniu wykorzystał wszelkie dostępne archiwalia - książęce, prywatne i miejskie - a także opracowania innych dziejopisów. W kilku miejscach Opisu miasta wspomina o swojej wcześniejszej pracy i przyznaje, że przejął z niej pewne fragmenty na potrzeby nowego utworu.

Powody powrotu do już raz opracowanego tematu wytłumaczył Friedeborn w otwierającym Opis miasta liście dedykacyjnym senatui populoque Stetinensi [radzie miejskiej i mieszkańcom Szczecina]:

Jakiśs czas temu [...] przedstawiłem jego pełną historię, teraz natomiast przedkładam krótki opis. Żywię jednak nadzieję, że nie zostanę uznany za osobę, która serwuje dwukrotnie gotowaną kapustę, skoro po raz drugi wyprowadza przed publiczność to samo, tyle że przyobleczone w rzymską szatę! [...] Jakkolwiek więc by było - czy opisy te odbiegają nieco od wcześniejszych, czy też mówią to samo o tym samym w tym jednak, jak się spodziewam, można by dostrzec wyraźniejszą różnicę, że to, co tam rozproszone, tu jest połączone, co tam podane pospolitą, tu łacińską mową, co tam jedynie dla obywateli, tu przeznaczone jest i dla obywateli i dla obcych. Dołączony został teraz także nie pozbawiony elegancji widok miasta, uzmysławiający i jego położenie, i charakter.

(Friedeborn, 2016: 41)

Warto zwrócić uwagę na ujawnionych w tym fragmencie adresatów dzieła: miało ono służyć nie tylko miejscowym, ale i cudzoziemcom. Wynika z tego jasno, że poprzez Opis miasta chciał Friedeborn przekroczyć granice własnego regionu, zainteresować Szczecinem także mieszkańców innych krajów Europy. To, naturalnie, tłumaczy zmianę medium językowego na wciąż jeszcze uniwersalną łacinę.

Właściwie jednak w pracy Friedeborna występują trzy różne języki. Podstawowy zrąb dzieła napisany został po łacinie, ale nazwy własne przytacza autor po niemiecku, najczęściej jako uzupełnienie nazwy łacińskiej, zdarza się jednak, że jako jedyne określenie danego miejsca czy obiektu. Natomiast pojedyncze słowa i zwroty w kilku miejscach książki, głównie w elementach ramy literacko-wydawniczej, poprzedzających tekst zasadniczy, przytacza Friedeborn w języku greckim.

Podczas prac przygotowujących przekład do druku należało więc podjąć decyzję, które elementy tekstu podać w tłumaczeniu, a które pozostawić w oryginalnej wersji językowej. Istotny dla przyjętych rozwiązań okazał się fakt, że tłumaczenie miało się ukazać równolegle z edycją oryginału dzieła. W części przekładowej po- 
stanowiono zachować niemieckie nazwy topograficzne, które w oryginale utworu służyły ujednoznacznieniu użytych przez Friedeborna nazw łacińskich. Pozostawione w przekładzie nazwy niemieckie pełnią tę samą funkcję wobec nazw polskich. Natomiast w nielicznych miejscach utworu, w których Friedeborn posłużył się wyłącznie nazwą niemiecką, jej tłumaczenie podano w objaśnieniu.

Inne rozwiązanie przyjęto wobec wtrętów greckich. Naturalnie, można je było pozostawić w tekście przekładu po to, by zaakcentować intencje autora - w tym przypadku popisowe, erudycyjne - i dać tłumaczenie w przypisie. Jednak dla współczesnego czytelnika, nawet tego z wykształceniem humanistycznym (które przecież nie uwzględnia już nauki greki), słowa napisane w tym języku - ze względu na odmienność alfabetu - byłyby jedynie nieczytelnym ciągiem znaków, który zaburzałby tok zdania i zmuszał do odcyfrowania znaczenia w przypisie. I w tym wypadku rozstrzygająca okazała się obecność oryginału po drugiej stronie książki. Czytelnik śledzący edycję równolegle z przekładem, najczęściej pewnie filolog klasyczny, dostrzeże i zrozumie erudycyjne wstawki greckie. Natomiast czytelnikowi przekładu na ich obecność w oryginale dzieła zwróci uwagę oznaczenie konkretnego fragmentu polskiego znacznikiem przypisu - bowiem tekst oryginalny i przekład związane zostały tą samą numeracją objaśnień, podanych u dołu każdej strony.

Zarówno przy przygotowywaniu edycji dzieła, jak i dla potrzeb przekładu, konieczne było rozwiązanie wszystkich skrótów występujących w tekście utworu. Czytelnicy starych druków mają świadomość ich nagromadzenia w dziełach drukowanych epok dawnych, zwłaszcza w tytulaturze, odnoszącej się do osób podpisanych pod różnymi elementami ramy literacko-wydawniczej, takich jak dedykacje, listy zalecające, przedmowy itd. Rozbudowana rama wydawnicza dziełka Friedeborna także nie odbiegała od tej normy.

Przyjrzyjmy się dla przykładu jednemu z listów zamieszczonych przed tekstem zasadniczym dzieła - epistole autora adresowanej do Jurgi Walenthina Winthera (1578-1623), dyplomaty i doradcy książąt pomorskich, ale także regionalnego historyka i przyjaciela Friedeborna. W nagłówku tego listu w starodrucznym wydaniu książki, bezpośrednio przed nazwiskiem autora, napotkamy tu skrót 'S.D.', a nieco dalej, po nazwisku, jeszcze 'S.S.S.' (Friedeborn, 1624: A A $_{3}$ ). Pierwsze ze skróceń możemy łatwo odnaleźć w pomocniczych kompendiach, np. w znakomitym słowniku skrótów łacińskich Marka Winiarczyka (1995). 'S.D.' pisane wielką literą autor ten proponuje rozwiązać jako Sanctissimus Dominus lub Saxoniae Dux, scientiae doctor, Spectabilis doctor, suis dedit, salutem dicit, senatus decretum, sine dato, sub dato, sub die, subscripta data, semel die czy wreszcie - sine die (Winiarczyk, 1995: 97). O wyborze właściwego rozwiązania musiał więc zadecydować kontekst, ewentu- 
alnie - podstawowa wiedza na temat podpisującej się osoby (nie każdy przecież był księciem Saksonii). W przypadku przywoływanego nagłówka wybór padł na zwrot salutem dicit [pozdrowienia przesyła] - usytuowanie nazwiska autora bezpośrednio po skrócie pozwoliło dokonać wyboru bez trudności i bez cienia wątpliwości.

Jednak przy rozwiązywaniu drugiego ze skrótów nie można się już było posłużyć tą samą metodą. Wprawdzie słowniczek Winiarczyka podaje rozwinięcia i dla tego skrócenia, np. sicut supra scripti czy Sacerdotes de Sanctissimo Sacramento (Winiarczyk, 1995: 104), ale żadne z nich nie pasuje do kontekstu, w jakim wystąpił skrót w Opisie miasta, gdyż usytuowanie 'S.S.S.' wskazuje, że kryć się pod nim muszą jakieś określenia bezpośrednio dotyczące autora. W sukurs przyszła uważna lektura innych części dzieła. W jednej z nich Friedeborn przedstawia się jako Stetinensis senator ac secretarius - jak widać, wszystkie te określenia rozpoczyna litera 'S'. Można więc z niezachwianą pewnością rozwiązać kombinację Paulus Friedebornius S.S.S. jako Paulus Friedebornius Senator Secretariusque Stetinensis, co oznacza po prostu: Paul Friedeborn, rajca i sekretarz szczecinski.

Ciekawy problem translatorski wywołał chronostych, umieszczony w zakończeniu tego samego listu ramowego (Friedeborn, 1624: $\mathrm{A}_{4} \mathrm{r}$ ). Przypomnijmy, że chronostych był jednym z najpopularniejszych gatunków poesis artificiosae, występującym w literaturze okolicznościowej XVII wieku, ale chętnie stosowanym także poza nią. Przy jego komponowaniu odwoływano się do rzymskiego systemu zapisu liczb, który wykorzystywał siedem liter alfabetu łacińskiego: I, V, X, L, C, D, M. Jeśli litery takie wystąpiły w wyrazach składających się na tekst utworu, mogły jednocześnie, po zsumowaniu, wyrazić datę jakiegoś wydarzenia. Aby wskazać na tę ich dodatkową funkcję, zwykło się je drukować większą czcionką (wersalikami). W zetknięciu z tak zorganizowanym tekstem, którego właściwy przekaz, jakim jest data, jest na innym, głębszym poziomie organizacji i uwidacznia się niejako „przy okazji”, tłumacz pozostaje niekiedy zupełnie bezradny. Należy wszak zauważyć, że część liter wykorzystywana do liczbowania rzymskiego nie występuje w zasadzie w leksyce polskiej ('x', 'v'). Niemniej, chronostychy, na fali popularności gatunków kunsztownych, wkroczyły przecież i do literatury polskiej. Z trudnością, jaką rodzi brak w naszym języku popularnej w łacinie litery 'v', radzono sobie przez oddawanie częstej w polskim, a nieobecnej w języku łacińskim, litery ' $w$ ' jako zdublowanego 'v’2. Sposób ten zastosował w swojej książce i Friedeborn przy zapisie w formie

2 Ciekawe przykłady takiej praktyki w literaturze polskiej tego samego czasu, zob. Borysowska, 1997: 25. 
zlatynizowanej niektórych niemieckich nazw własnych, np. Brunsvviga (zamiast Brunswiga). Chronostych skomponowany przez Friedeborna wygląda następująco:

VIrtVs DeI In InflrMItate perfICItVr

Po zsumowaniu wartości liczbowej wyróżnionych liter otrzymamy liczbę 1623, która stanowi datę roczną listu napisanego do Winthera. Jednak dosłowny sens tego wersu także jest dość istotny (co w przypadku chronostychów nie zawsze było norma). W wiernym tłumaczeniu znaczy to tyle co „Siła (władza) Boga uwidacznia się w słabości (chorobie)”. Zdanie to doskonale przystaje do ostatniego akapitu listu, w którym Friedeborn odnosi się do ciężkiej choroby Winthera - pisze o zanoszeniu modlitw w intencji ozdrowienia przyjaciela i kieruje ku niemu słowa wsparcia. Usytuowanie chronostychu w takim kontekście spowodowało, że także jego podstawowe znaczenie wydawało się być ważne i warte oddania. Odnalezienie i stworzenie właściwej kombinacji z kilku polskich słów, która jednocześnie odzwierciedliłaby obydwa poziomy zastosowanego przez Friedeborna kodu, było dość trudne. Szczególnie znalezienie odpowiednika dla słówka 'virtus', powszechnie rozumianego jako 'cnota', ale tu oznaczającego raczej 'moc', 'potęgę', 'ogrom', nastręczało pewnych trudności, jeśli się chciało, żeby odpowiednik ów zawierał jednocześnie którąś z liter-cyfr rzymskich, najlepiej 'D'. Ostatecznie zdecydowano się na następujące tłumaczenie, które zawiera zakodowaną (choć przy użyciu innych znaków) datę 1623 i w przybliżeniu oddaje ogólny sens oryginału (Friedeborn, 2016: 50):

BezDeń Boga VVypełnIa sIę VV nIeMoCy

$\mathrm{O}$ ile więc w konfrontacji z chronostychem udaje się niekiedy przekroczyć, nieprzekraczalną na pierwszy rzut oka, granicę przetłumaczalności, o tyle nieprzebytą „rafą” znaczeń, o którą rozbijają się wszelkie wysiłki tłumacza, są zwykle gry słów. To, co brzmi tak samo, a niesie odmienne znaczenie w jednym języku, nie zawsze musi mieć (a najczęściej nie ma) odpowiednik w drugim. Przyjrzyjmy się popularnemu wierszykowi opisującemu Stralsund, który przytoczył autor innego listu ${ }^{3}$ zapowiadającego dzieło Friedeborna (Friedeborn, 1624: $\mathrm{B}_{1} \mathrm{r}$ ):

Annis ducentis, ter denis, mille retentis,

Facta Stralaesundis est urbs, cui nomen ab undis.

3 Jest to list pochwalny Daniela Cramera (1568-1637), teologa i historyka pomorskiego. 
Nawet osoba nie znająca łaciny, dostrzeże (lub usłyszy) zawartą w drugim wersie dwukrotność słówka 'undis' i domyśli się obecności gry słów. Rzeczywiście, wers ten nawiązuje do wystąpienia w przytoczonej, łacińskiej nazwie miasta, przypadka zależnego od rzeczownika 'unda', co znaczy 'fala'. Tak więc czytelnik oryginalnej wersji tekstu nie tylko ma możliwość skonstatowania, że miasto Stralsund ma w swej nazwie „fale” (co jest dosłownym sensem tego wersu), ale i unaocznia to sobie, odnajdując powtórzone 'undis' i w przywołanej nazwie, i w zakończeniu wiersza. Niestety, po polsku Stralsund bywa co najwyżej nazywany Strzałowem, nigdy jednak... „Strzałfalami”. Rolą tłumacza było więc w tym przypadku tylko dosłowne oddanie treści wierszyka i zwrócenie uwagi czytelnikowi przekładu na utraconą grę słów w objaśnieniach (Friedeborn, 2016: 55):

Dodaj tysiąc do roku dwieście trzydziestego, Wtedy powstał Stralsund, z falami w nazwie jego.

Po elementach wprowadzających, którymi są w książce Friedeborna wspomniane wyżej listy, tekst główny rozpoczyna autor od rozdziału zatytułowanego, tak jak całe dzieło, Descriptio. Tłumaczy w nim pokrótce nazwę miasta, jego położenie, układ urbanistyczny, wyjaśnia pochodzenie mieszkańców. Wymienia tu także i opisuje przedmieścia, odnotowuje zbiorniki wodne, rzeki, groble itd. Omawia także kwestię żyzności okolicznych ziem i opisuje obfitość ryb, jakiej dostarczają otaczające miasto akweny. W kolejnych rozdziałach charakteryzuje poszczególne typy działających w mieście instytucji (De templis, De coenobiis et xenodochiis, De scholis) oraz wyjaśnia organizację republiki miejskiej (Arx ducalis, Forma Reipublicae Stetinensis). W rozdziale zatytułowanym Historica, przedstawia zwięźle kluczowe momenty dla dziejów miasta, włączając w tok swojej opowieści obszerny passus autorstwa Alberta Krantza, opisujący rozruchy miejskie i konflikt powstały wokół wzniesienia w mieście zamku pomiędzy księciem Kazimierzem V a szczecińskimi rajcami.

Pewnych trudności w przekładzie tej partii tekstu nastręczało właściwe tłumaczenie nazw własnych elementów topograficznych lub fizjograficznych występujących w mieście i jego otoczeniu. Jak się okazało w toku prac translatorskich, istotne znaczenie miała konstatacja, że Friedeborn na potrzeby swojej pracy tłumaczył na łacinę niemieckie nazwy właściwe jego czasom, nie zawsze odpowiadające nazwom późniejszym, tak niemieckim, jak i polskim. Z kolei posługując się nomenklaturą łacińską, nie zawsze korzystał z nazw występujących w starszych źródłach. Przykładowo: dziwnie brzmiąca po polsku nazwa Zalew Świeży dla określenia Zalewu Szczecińskiego, jest dosłownym odpowiednikiem przytoczonej przez Friedeborna łacińskiej formy Lacus Recens i niemieckiej nazwy tego akwenu, jakiej użył - Frisches 
Haff (Friedeborn, 1624: $\mathrm{C}_{2} \mathrm{r}$ ). Ta ostatnia funkcjonowała w czasach Friedeborna obocznie do nazwy Stettiner Haff, która z biegiem lat stała się jedyną używaną i zastąpiła wszystkie inne. Z kolei nazwa Frisches Haff stała się z czasem określeniem stosowanym wyłącznie dla Zalewu Wiślanego i nawet współczesnym Niemcom nie kojarzy się zapewne z tą zatoką Bałtyku, do której wpada Odra.

Dużo większym wyzwaniem okazało się właściwe przełożenie łacińskiej nazwy Navale Magnum, którą ujednoznacznił Friedeborn niemieckim określeniem Die Große Lastadie (Friedeborn, 1624: $\mathrm{B}_{3} \mathrm{v}$ ), co tradycyjnie tłumaczy się jako Wielka Łasztownia. Jednak Friedeborn nie przetłumaczył nazwy niemieckiej przy użyciu łacińskiego słówka 'lastadium' lub 'lastagium', a poprzez - niewystępujące w żadnych wcześniejszych określeniach tego miejsca - 'navale', które współczesne słowniki łacińskie kazałyby tłumaczyć jako 'przystañ' lub 'doki'. Navale Magnum trzeba by wówczas rozumieć jako Wielkie Doki, ale takiej tradycji nazewniczej opisywany przez Friedeborna obszar nigdy nie miał. Sprawę komplikował fakt, że w tym samym rejonie miasta, to jest na wyspie Łasztownia, istniało inne miejsce, do którego bardziej pasowałoby określenie Wielkie Doki. Była to stocznia, o której Friedeborn wspomniał, posługując się z kolei wyłącznie niemiecką nazwą Schiffsbawer Lastadie (Friedeborn, 1624: $\mathrm{B}_{3} \mathrm{v}$ ).

Problem pomogła rozwiązać lektura słowników obowiązujących w czasach Friedeborna. W jednym z nich, dziele niderlandzkiego leksykografa i językoznawcy Corneliusa Kiliaana (1528-1607), niemieckie słówko 'lastagie' opisuje się następująco: „navale, locus ubi naves constituuntur, aedificantur aut quassatae reparantur [doki, miejsce w którym konstruuje się, buduje albo naprawia zepsute statki]" (Kiliaan, 1599: 274). Jak więc można przypuszczać, Friedeborn, szukając łacińskiego odpowiednika dla niemieckiej nazwy Die Große Lastadie, skorzystał z podpowiedzi jakiegoś dawnego słownika i umieścił w swojej książce niestosowaną wcześniej i nieznaną wcześniejszym źródłom nazwę Navale Magnum.

Zarówno zagadnienia podjęte w Opisie miasta, jak i ich kolejność, wskazują na opanowanie przez Friedeborna teoretycznych zasad konstruowania tego typu deskrypcji. Wykształceni przedstawiciele renesansu i baroku mieli w nich doskonałe rozeznanie. Tradycja opisu miast ukształtowała się jeszcze w starożytności, a wiedzę tę zebrał i usystematyzował Menander z Laodycei (III w. n.e.). Traktat Menandra od początków XVI w. stał się szerzej znany, dzięki zamieszczeniu go w przekładzie łacińskim w pierwszym tomie zbioru Rhetores Graeci (1509), który wydała słynna wenecka oficyna Alda Manucjusza. Zasady opracowane przez starożytnych - oprócz Menandra, można tu przywołać także np. Kwintyliana (ca 35 - ca 96) - przejęli i rozwinęli teoretycy czasów nowożytnych, np, Gerardus Bucoldianus (1527-1594) 
w rozprawie De inventione et amplificatione oratoria (1534). W dziele Friedeborna łatwo odnajdziemy tradycyjną topikę zalecaną przy tworzeniu deskrypcji miast przyjrzyjmy się przykładowo przypadku dzieła Friedeborna łatwo można dostrzec zgodnościć jego utworu z zaleceniami sformułowanymi jeszcze przez wspomnianego Kwintyliana (Institutio oratoria III, 7, 26) - by miasto chwalić tak jak człowieka. Mamy więc Już w pierwszych zdaniach opisu dostrzeżemy informację o „rodowodzie” miasta w postaci odwołania do wspomnianych w dziele Ptolemeusza mitycznych Sidinów, a następnie do niemieckich kolonistów z Magdeburga i Brunszwiku, dzięki którym miasto zostało lokowane na prawie niemieckim i zaczęło się znakomicie rozwijać. W dalszej części, poprzez opis wyglądu Szczecina (położenie, ważniejsze obiekty architektoniczne) oraz jego organizacji (instytucje miejskie, ustrój), nawiązuje autor do Kwintylianowego schematu pochwał „ciała i ducha” (corpus et anima). Po tym, w rozdziale zatytułowanym Historica, skupia się na wskazaniu ważnych dokonań mieszkańców (gesta), by wreszcie w podsumowaniu (Appendix) dokonać ostatecznej pochwały miasta jako miejsca, które omijają kataklizmy przyrodnicze i które umiało wykorzystać swoje położenie dla nadzwyczajnego rozwoju, stwarzając mieszkańcom dogodne warunki do życia.

Z punktu widzenia Friedeborna jedną z najistotniejszych cech Szczecina, która zadecydowała o dobrobycie miasta, był dobrze rozwinięty handel, a jego podstawę od najdawniejszych czasów stanowiły ryby. Toteż właśnie wychwaleniu mnogości gatunków ryb, jako widomego dowodu łaski Stwórcy, oddaje się autor już od pierwszego rozdziału swojej książeczki:

Świeżych ryb dostarczają nie tylko różne wspomniane już kanały rzeczne płynące powyżej i poniżej miasta, lecz przede wszystkim niezbyt odległy Zalew Świeży [das Frische Haff]. (...) ten, tocząc dalej słodkie wody, wciśnięty między morze i Odrę i rozlany na kształt zatoki morskiej na 8 mil niemieckich długości i cztery szerokości, tak bardzo obfituje w ryby, że stanowi dogodną spiżarnię i jakby staw rybny dla miasta i innych okolicznych miejscowości. To właśnie decyduje o bogactwie ryb i ich bardzo dużym wyborze, tak zimą, jak i latem. A nawet, co jest godne podziwu, pojedyncze miesiące przynoszą nowe rodzaje ryb, wprowadzając radosne urozmaicenie tak, że wydaje się, iż rzeka może konkurować w tym zakresie z Nilem, albo też zbierać za to tak liczne pochwały jak ziemia święta. Nie można by łatwo znaleźć nawet podobnego, a cóż dopiero lepszego rynku rybnego w żadnym mieście Niemiec, a to dzięki tak wielkiej łaskawości Boga, któremu niech będzie chwała i sława.

(Friedeborn, 2016: 71, 73)

Rozwinięciem i uzupełnieniem opisu zasobności okolicznych wód w ryby jest zamieszczony na końcu książki katalog gatunków ryb, sporządzony równolegle po 
łacinie i niemiecku. Oprócz wymienienia z nazwy tych gatunków, które można łowić stale w otaczających Szczecin wodach, wylicza tu także Friedeborn pięć występujących okresowo. Na koniec zaznacza, że spis nie jest zamknięty, gdyż nie wszystkie rodzaje dostępnych ryb udało się dotąd rozpoznać.

Jak zauważa Marek Skwara, „w danej literaturze katalogi ryb to prezentowanie przez twórcę własnej erudycji, warsztatu retorycznego, możliwość perswazyjnego ukazania idealnego obrazu różnych grup społecznych (ziemiaństwa, mieszczaństwa), wreszcie pokazania człowieka jako tego, który podporządkowuje sobie przyrodę, jest jej zdobywcą i biesiadnikiem" (Skwara, 1993: 77). W przypadku dzieła Friedeborna najistotniejszy jest motyw perswazyjny - katalog ryb jest jednym z najważniejszych argumentów na rzecz uznania Szczecina za miejsce stwarzające znakomite warunki do życia.

Warto nadmienić, że wyliczenie ryb, pokrywające się w dużej mierze z niemieckojęzyczną wersją katalogu Friedeborna, zawierała także słynna mapa Pomorza Eilharda Lubinusa (1565-1621), wydana kilka lat przed Opisem miasta, w 1618 roku. Wykaz został tu umieszczony jako zwieńczenie opisu Pomorza, zatytułowanego Pomeraniae et rerum in ea memorabilium brevis descriptio [Krótki opis Pomorza i z nim związanych godnych pamięci spraw] (Cieśluk, 2013: 404-405). Należy zaznaczyć, że ze względu na szczupłość miejsca - tekst wkomponowany jest przecież w mapę - opis ma charakter bardzo syntetyczny. Jak zauważa tłumaczka:

Zawarte w tekście szczegóły i ciekawostki eksponują cechy kraju uznane przed niemal czterystu laty za najbardziej charakterystyczne. Poszukując dziś przesłanek do określenia regionalnej tożsamości Pomorza, możemy odnaleźć jej historyczne podstawy właśnie w opisie Lubinusa. Jest zatem Pomorze krainą nadwodną: rozłożoną wzdłuż brzegu morza i zalewu oraz wokół rzek i ogromnej liczby jezior. Za znak firmowy Pomorza z powodzeniem można uznać ryby: morskie i słodkowodne, od najbardziej pospolitych po okazy wyjątkowe.

(Cieśluk, 2013: 378)

Także w dziele młodszego nieco od Friedeborna Johannesa Micraeliusa (1597-1658) - monumentalnej historii Pomorza przedstawionej w sześciu księgach - znajdujemy wyliczenie ryb dostępnych w pomorskich akwenach (Micraelius, 1639: 384). Jest ono na tyle zbieżne z tym, co zawiera Opis miasta, że możemy przypuszczać, iż zostało z niego przejęte.

Niestety, ten ważny, choć drobny fragment dzieła Friedeborna, jakim jest wykaz ryb, nastręczył największych trudności translatorskich. Jak już nadmieniono, kata$\log$ zawiera nazwy ryb występujących w akwenach otaczających Szczecin w dwóch językach - po łacinie i niemiecku. Mamy prawo przypuszczać, że - wzorem to- 
ponimów - Friedeborn dopasowywał łacińskie nazwy ryb do używanych w jego czasach nazw niemieckich, według stanu swojej wiedzy i, być może, w oparciu o jakieś kompendium, którego jednak nie udało się odnaleźć. Pozostawienie w tekście niemieckich nazw ryb pozwala przypuszczać, że sam autor nie był pewny jednoznaczności zastosowanych terminów łacińskich. Pozostawił więc nomenklaturę niemiecką w celach ujednoznaczniających, tak jak to zrobił przy nazwach miejscowych wewnątrz książki. Ponadto i w tej partii tekstu nie znalazł odpowiednika łacińskiego dla nazw wszystkich gatunków i kilka z nich wymienił tylko po niemiecku.

Należy wyjaśnić, że określenia łacińskie użyte przez Friedeborna nie mają nic wspólnego z nazwami poszczególnych taksonów stosowanymi obecnie w systematyce organizmów. Podstawy współczesnej nomenklatury zoologicznej stworzył szwedzki przyrodnik, lekarz i profesor Uniwersytetu w Uppsali, Carl von Linné (Linneusz, 1707-1778). Zasady tzw. binominalnego systemu nazewniczego dla zwierząt uczony ten przedstawił w 10. wydaniu swojej pracy Systema Naturae z 1758 roku, a więc ponad 130 lat po publikacji Opisu miasta Friedeborna. Nazw użytych przez Friedeborna trzeba więc było szukać w starszych słownikach łacińskich i niemieckich (Mayer, 1648; Prasch, 1686). Niestety, nawet przy odwoływaniu się do tych źródeł, nazwa niemiecka wskazywała niekiedy na inny gatunek niż łacińska a w kilku przypadkach, bez bardzo specjalistycznej wiedzy, w ogóle nie udało się ustalić, o jakim gatunku mowa.

Osobnym problemem było włączenie przez autora do katalogu ryb innych zwierząt (nie ryb), takich jak bobry czy foki. Jak się jednak okazało, praktykę taką można zaobserwować także w innych pomorskich zestawieniach. Na przykład we wspomnianym już wykazie Lubinusa znalazły się kraby i raki (Cieśluk: 404-405), a w spisie odnotowanym w dzienniku podróży augsburskiego kupca goszczącego w Szczecinie w 1617 roku, Filipa Hainhofera, foki i raki (Hainhoher: 63). Najwyraźniej w ówczesnym przekonaniu rybą można było nazwać każde zwierzę żyjące w środowisku wodnym.

Opublikowana właśnie edycja i przekład dzieła Friedeborna wpisują się w chętnie podejmowaną w ostatnich latach przez historyków literatury tematykę deskrypcji miast i literatury peregrynackiej (Krzywy: 73-74). Tekst ten może być jednak przedmiotem zainteresowania badaczy innych dyscyplin, w tym językoznawców, historyków kultury, specjalistów edytorstwa, a nawet dziedzin tak odległych od

4 Np. nazwa łacińska Trutta aureola wskazywała na pstrąga potokowego, a niemiecka der Goldfisch - raczej na jakiś gatunek karasia. 
humanistyki, jak ichtiologia. Książka stanowi przy tym odpowiedź na formułowany przez środowisko historyków postulat udostępniania tekstów źródłowych, zwłaszcza w przekładzie, opisujących przeszłość miasta i regionu. Ta potrzeba, ze względów historycznych, jest na Pomorzu Zachodnim szczególnie głęboka. Widoczne w ostatnich latach zainteresowanie dziejami ziem pomorskich i samego miasta stwarza ponadto nadzieję, że interesujący opis Friedeborna, niedostępny dotąd z powodu bariery językowej, znajdzie szersze grono czytelników również w kręgach nieprofesjonalnych, wśród współczesnych mieszkańców miasta.

\section{Bibliografia}

Borysowska, Agnieszka. „Andrzej Loeaechius i jego twórczość poetycka”. Slavia Occidentalis 54 (1997): 17-28.

Borysowska, Agnieszka. „Wstęp”. Opis miasta Szczecina. Paul Friedeborn. Oprac. i przełożyła Agnieszka Borysowska. Warszawa: Sub Lupa, 2016. 5-31.

Cieśluk, Małgorzata. „Eilharda Lubinusa «Krótki opis Pomorza» - słowo od tłumaczki”. Eilharda Lubinusa podróż przez Pomorze. Red. Radosław Skrycki. Szczecin: Zamek Książąt Pomorskich, 2013. 375-382.

Friedeborn, Paul. Descriptio urbis Stetinensis, topographica, historica cum icone, Genium Loci adumbrante conscripta in Dei sospitatoris laudem, iustam patriae devotionem. Stetini: typis Nicolai Bartholdi, 1624.

Friedeborn, Paul. Opis miasta Szczecina. Oprac. i przełożyła Agnieszka Borysowska. Warszawa: Sub Lupa, 2016.

Gruchała, Janusz S. „Uwagi o wydawaniu prozy staropolskiej”. Terminus IX.2 (2007): $15-35$.

Hainhofer, Filip. „Filipa Hainhofera dziennik podróży, zawierający obrazki z Frankonii, Saksonii, Marchii Brandemburskiej i Pomorza w roku 1617”. Przekład i oprac. Krzysztof Gołda. Źródta do Dziejów Pomorza Zachodniego IX (2000): 13-172.

Kiliaan, Cornelius. Etymologicum Teutonicae linguae, sive Dictionarium Teutonico-Latinum. Antverpiae: Moretus, 1599.

Krantz, Albert. Wandalia. Coloniae: Joannes Soter alias Heil et Socii, 1519.

Krzywy, Roman. Wędrówki z Mnemozyne. Studia o topice dawnego podróżopisarstwa. Warszawa: Muzeum Pałac w Wilanowie, 2013.

Mayer, Johann. Vocabularium majus, latino-germanicum in V. libros divisum, quorum I. est Scholasticus, II. Ecclesiasticus, III. Politicus, IV. Physicus et Medicinalis, V. Oeconomicus ... in usum Scholae Ulmensis. Ulmae: Kühne, 1648. 
Micraelius, Johannes. Sechstes und Letztes Buch Von deß Pommerlandes Gelegenheit und Ein-Wohnern. Bd. 6. Stettin: Georg Rhete, 1639.

Migdalski, Paweł. „Stan i potrzeby polskojęzycznych edycji źródeł do dziejów Księstwa Pomorskiego". Piśmiennictwo na Pomorzu Zachodnim do końca XVIII w. Red. Janina Kosman. Szczecin: Wydawnictwo Archiwum Państwowego „Dokument”, 2015. 9-32.

Prasch, Johann Ludwig. Organon latinae linguae, oder Neue deutliche Lehrart, wie man die gut-Lateinische Sprache ... lehren ... kan ..., Regenspurg: [s.n.], 1686.

Skwara, Marek. „Ryby w świecie ziemiańskiego dobrobytu (od sztuki kulinarnej do retoryki)". Z warsztatu badawczego humanistyki: materiaty I Sympozjum Mtodych Pracowników Nauki Wydziatu Humanistycznego, Uniwersytet Szczeciński, 8-10 maja 1991. Red. Robert Cieślak, Ewa Tierling, Piotr Urbański. Szczecin: Wydawnictwo Naukowe Uniwersytetu Szczecińskiego, 1993. 67-81.

Winiarczyk, Marek. Sigla Latina in libris impressis occurenta cum siglorum Graecorum apendice. Wrocław: Wydawnictwo Uniwersytetu Wrocławskiego, 1995.

\section{Szczecin and Fish. About the Translation of Paul Friedeborn's (1572-1637) Description of the City}

\section{Summary}

The subject of this article is the work of Paul Frideborn Descriptio urbis Stetinensis [The description of the city of $S z c z e c i n]$, a new edition and Polish translation of which has been published in 2016. This prose description of the city was first published in Szczecin in 1624. During this period Szczecin was the capital of the Duchy of Pomerania, a Hanseatic city, organized as a civic republic and ruled by a community of wealthy patricians. Friedeborn, a councilor and secretary of the city who dedicated his work to Szczecin's city council, was himself a part of this environment. The work was written in Latin and is a laudation constructed according to patterns popular in Friedeborn's times, which were derived from Quintillian's advice: to praise the city as if a man, that is, by the description of his origin (in this case - information about the founding of the city), attributes of "body and spirit" (i.e. the issues concerning the organization and municipal institutions) and deeds (regarded as residents' achievements). An interesting persuasive part of the work is a catalogue of fish inhabiting the rivers and reservoirs surrounding the city. The catalogue, present also in other works describing Pomerania in the time, indicates the main source of the region's natural wealth and serves as a showcase for the region. This element proved to be especially challenging to translate, due to differences in historical and contemporary fish names. Other translation 
problems have been pinpointed in the article, such as abbreviations, the translation of the chronogram, proper nouns, etc.

Keywords: comparative literature, translation studies, editorship, 17th century Latin literature, city descriptions, Duchy of Pomerania, laudation, rhetoric

Słowa kluczowe: literaturoznawstwo porównawcze, translatoryka, edytorstwo, literatura łacińska XVII w., deskrypcje miast, księstwo pomorskie, laudacja, retoryka 